\title{
Ultrastructural features of some integumental structural of Lernanthropus kroyeri Van Beneden parasitic copepoda (Siphonostomatoidae, Lernanthropidae)
}

\author{
Shereen A. Fahmy* \\ Zoology Department, Faculty of Science, Damietta University, Egypt
}

Received: 24 May 2015 / Accepted: 16 September 2015

*Corresponding author: shereenfahmy80@yahoo.com

\begin{abstract}
Lernanthropus kroyeri (Copepoda, Siphonostomatoida: Lernanthropidae) is a gill parasite found on the sea bass Dicentrarchus labrax. It was significantly present during spring and summer, agreeing with a period of increasing temperature. Due to this, it shows morphological modifications, which are studied through scanning electron microscopy. This study made it possible to reveal some superficial structures associated with the tegument, in particular, sensory structures and anchoring organs were studied to illustrate the possible functions of these structures. On the body surface, several types of epicuticular formations were identified: very plenty ones with a tubular or filamentous aspect, which provides the copepod with a considerable increase of cuticular surface in order to a better oxygen usage, and so improving respiratory processes through the integument; the other type of cuticular formation consists of longer and more manifold expansions less abundant than the other ones, and they have mainly a sensory function.

Uniciliated sensory structures, not mounted on papillae and protruding from pits, occur regularly on all body surfaces, except on antennae and maxillipeds. These receptors show variation in distribution and morphology.
\end{abstract}

Keywords: Parasitic copepods, Lernanthropus kroyeri, Dicentrarchus labrax, integument, ultrastucture.

\section{Introduction}

Parasites play a particularly prominent role in aquatic ecosystems where they can dominate the biomass and productivity of the food webs in which they occur by Kuris et al., (2008). As in many parts of the world, aquaculture production in the Mediterranean has been expanding rapidly over recent years. The continuous decline of ocean fisheries and the increasing global fish consumption have promoted the rise of aquaculture. The need for increased supplies of aquatic foods to meet the growing demands of an expanding population is well recognized (FAO 2010; Guo and Woo 2009). Parasites are often inconspicuous relative to other members of aquatic 
communities research into the influence of parasites in aquatic environments has been limited to a few well-studied ecosystems (Lafferty et al., 2008). The success of the seacage farming is essentially correlated with the possibility to reduce production cost; however, the difficulty of managing disease within seacages is regarded as a major drawback (Ernst $e t$ al., 2002). Cultured fish may develop higher parasite burdens than those present in wild fish populations because the development of innovative culture techniques and rearing conditions can favor parasite outbreaks resulting in significant economical losses (Ghittino et al., 2003; Johnson et al., 2004). Fishes reared in aquaculture mostly acquire ectoparasites associated to several cases of deaths in culture systems (Mladineo 2007).

One of better-known example is the infection of fish with gill copepods, which do exert an important ecological and economical impact on awide array of fish species (Ragias et al., 2004). Human activities, including those in or adjacent to aquatic environments, can have a pronounced effect on the emergence of disease (including parasites; (Daszak et al., 2000), with implications for human health (Jones et al., 2008) and wildlife (Dobson and Foufopoulos 2001). Because anthropogenic activities increasingly alter the distribution and abundance of parasites (McKenzie, 2007; Morand and Krasnov, 2010; Polley et al., 2010) the ability to predict and mitigate the consequences of emergent infections depends, in part, on our understanding of how human activities influence the role of parasites in ecosystems. Previous observations revealed that Caligidae or Lernanthropidae are both dominant copepods parasites affecting fish species of great economic interest under rearing conditions (Raibaut et al., 1998). The european sea bass Dicentrarchus labrax is one of the main cultured fish species in the Mediterranean area. It represents an important financial source in the Mediterranean, especially in Corsica (Antonelli, 2010).

Lernanthropus kroyeri Van Beneden, belonging to Lernanthropidae, is commonly found in the Mediterranean caged-reared sea bass (Manera and Dezfuli, 2003).

Previous studies have already highlighted the presence of this parasite species, but they have focused primarily on their general morphology and pathologies (Manera and Dezfuli, 2003; Abu Samak 2004; Ozel et al., 2004; Toksen et al., 2006; Fahmy, 2014). Data on the pathological effects have been well documented in several studies. Investigations revealed that infections through the attachment of parasites and active feeding on mucus and epithelial cells of host fish by large populations could cause severe damages such as necroses, hemorrhages, inflammation, and mucus hyperproduction (Noga, 2000; Manera and Dezfuli 2003; Ragias et al., 2004; Abu Samak, 2005; Fahmy, 2014). The relation between the structure of appendages and their possible functions have been studied on the copepod parasite, with Lernanthropus kroyeri (Khidr et al., 2014).

The tegument is an important interface for interactions between host and parasite (Antonelli, 2010) therefore the current study was made to reveal the body surface of Lernanthropus kroyeri parasite using scanning electron microscope examination on some unreported superficial structures associated with the tegument, in particular, sensory structures and anchoring organs.

\section{Materials \& Methods}

Ultrastructural studies were carried out on the gills of cultured seabass Dicentrarchus labrax from Damietta province, that were naturally infested with Lernanthropus kroyeri van Beneden, 1851. Twenty sea bass Dicentrarchus labrax were examined for the presence of parasites. Body surface (skin, fins) and gills of the fish were examined. Gill arches were carefully removed and studied in a fresh condition. Copepods were identified using a light microscope according to the description done in previous studies (Ozel et al., 2004; Toksen et al., 2006). Seven specimens of $L$. kroyeri were studied using scanning electron microscopy. The copepods were removed alive from their hosts, washed repeatedly with seawater to free them from mucus, fixed in cold $\left(4^{\circ} \mathrm{C}\right) 2.5 \%$ glutaraldehyde in $0.1 \mathrm{M}$ sodium cacodylate buffer at $\mathrm{pH} 7.2$, dehydrated through a graded ethanol series $(30 \%, 50 \%, 75 \%, 90 \%$, and $100 \%$ ), critical-point-dried, and sputtercoated with gold/ palladium. Samples were examined under JEOL JSM-6510LV scanning electron microscope operated at an accelerating voltage of $30 \mathrm{kV}$.

\section{Results}


Ten out of the 20 sea bass gills sampled were infected with Lernanthropus kroyeri. Adult female copepods were attached to the flat, lamellae bearing sides of the primary lamellae (gill filaments) by their second antennae and third legs. The body of each parasite was positioned between the hemibranchs, attached to the internal face, with their axis parallel to the primary lamellae axis and with their cephalic extremities oriented towards the gill arch.

Scanning electron microscopy (SEM)
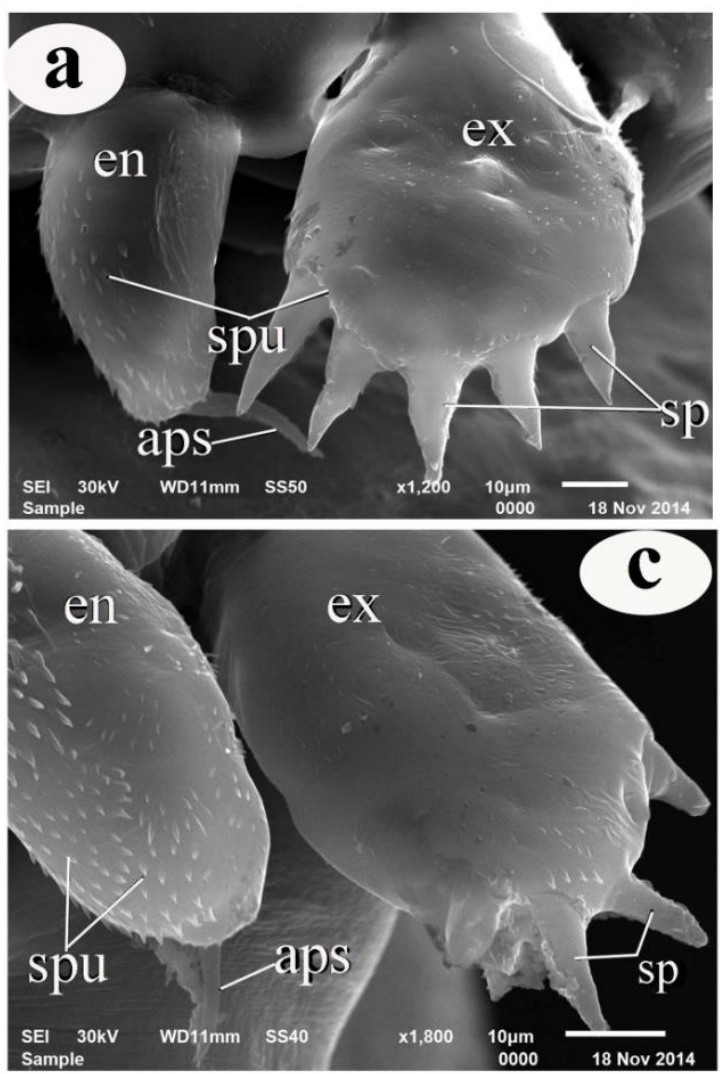

Fig. 1: Cuticular structures on both sexes of L. kroyeri. a Second leg of male. Exopod (ex) provided with spines (sp) and spinules (spu); endopod (en) with an apical seta (aps). b Genital area of male, abdomen (a), anal slits (ans), dorsal plate (dp), setae (se) and uropods (ur). c Second leg of female. Exopod (ex) provided with spines (sp) and spinules (spu); endopod (en) with an apical seta (aps). d Genital area of female, abdomen (a), $4^{\text {th }}$ thoracic leg (14), setae (se) and uropods (ur).

\section{Tegument structures}

Several types of presumed sensory structures and cuticular outgrowths were identified on the body surface of L. kroyeri.

1- Aesthetascs were identified on the antennules (Fig. 2a\&b).

2- Minute tegumental structures such as spines, setules, denticles, teeth and rows with various forms and sizes were observed on the body surface and appendages (Figs.1(a,b,c,d) \& 2(c,d, e\&f).
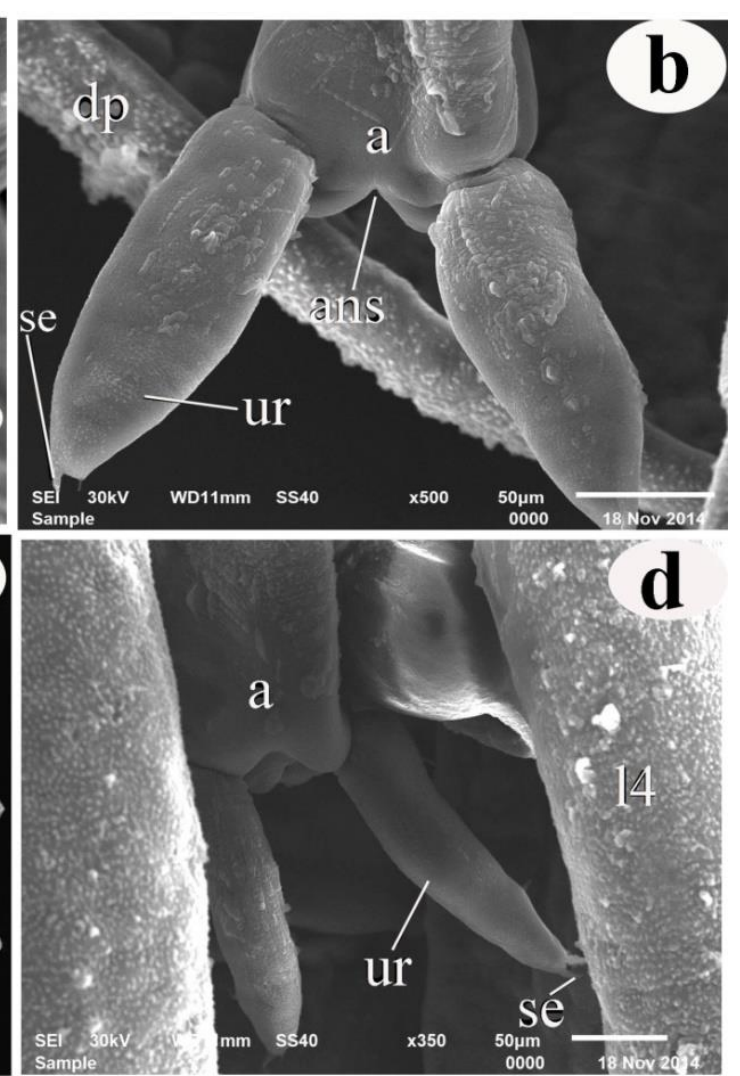

observations provided useful information on the integument structures of Lernanthropus kroyeri. Cephalothorax bears five pairs of cephalic appendages (antennules, antennae, maxillules, maxillae, and mandibles) and two pairs of thoracic leg appendages. The trunk, consisting of posterior part of the thorax and the abdomen, bears two or three pairs of legs according to sex, the genito-abdominal complex, and caudal rami. 


\section{Discussion}

Comparing with other crustacean groups, parasitic copepods have the most various structures and lifestyles (Lee et al., 2005).
Surface morphology, especially the number, shapes, size, and distribution of various tegumental structures may be helpful to understand the life and physiological condition of parasites.
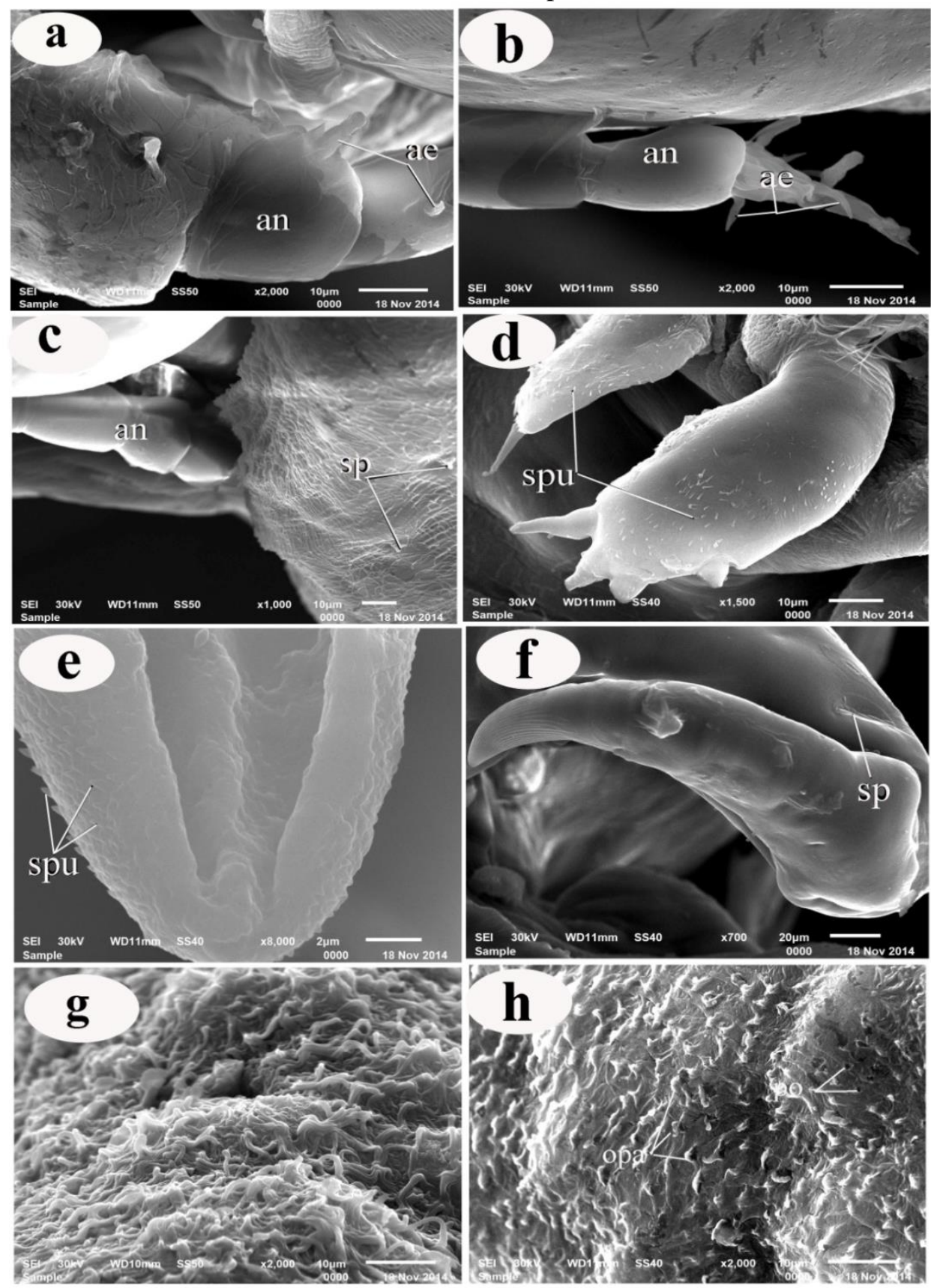

Fig. 2: Sensory structures of L. kroyeri. a Antennule, (an) at the base part, bearing Aesthetascs (ae). b Antennule, (an) at the distal part, (an) bearing Aesthetascs (ae). c,d,e,f details of tegument features: c cephalothorax with antennules (an) and spines (sp) . d $2^{\text {nd }}$ leg, spinules (spu). e mouth tube, spinules (spu). f maxillipeds, spine (sp). $\mathbf{g}$ Details of fine, dense, and intermingled setae occurring on dorsal body surface and legs. $\mathbf{h}$ Details of ornamented papillae (Opa) bearing cilium observed near the first and second leg, and pores (Po).

\section{Tegument structures}

Numerous sensory endings identified on body surface of L. kroyeri are involved with feeding and attachment. Also, provided the copepod with a considerable increase of cuticular surface in order to a better oxygen utilization, and so improving respiratory processes through the integument 
(Antonelli, 2012).

Recent studies have revealed remarkable diversity of parasitic copepod sensory abilities and behaviors. Body surface of parasites is richly equipped with numerous receptors, most of them may be with functional significances, monitoring chemical and mechanical signals from surrounding environment such as reported with (Heuch et al., 2007). Scanning electron microscopy examination of L. kroyeri during the present investigation made it possible to reveal some previously unreported superficial structures in this species. Several types of sensory structures identified on L. kroyeri were resembled such as previously observed in other copepods, and the form and distribution varies according to species (Boxshall et al., 1997). It is now widely accepted that, for successful mate recognition (and copulation), most copepods rely heavily on sensory modalities such as mechano- and/or chemoreception. Ohtsuka and Huys (2001) mentioned that Aesthetascs present on the antennules are chemoreceptors able to detect changes in water movement, dissolved chemical substances, information about detection of food, mate tracking, and/or in the exchange of chemical information between both sexes. Numerous sensory endings identified on body surface of $L$. kroyeri are involved with feeding and attachment. Cuticular differentiations play a secondary role in the fixation. Setae occurring on the antennules are used in guiding copepod to a prospective host (Gresty et al., 1993).

Most parasites copepods feed by rasping at the surface of their host using their appendages. Sensory endings present near the oral cone, on maxillules and maxillae, are presumably mechanoreceptors involved with feeding, while the length and flexibility of dense uniciliated sensory endings occurring in the dorsal body surface, or near legs of L. kroyeri, suggest that they may be rheoreceptors/tangoreceptors involved in the orientation of the parasite in relation to the flow of the ventilation water currents.

The cuticle of Lernanthropus kroyeri may provide the principal interface between the organism and its external environment. Amongst other functions it acts as a defense against pathogens / host attack, constitutes a barrier mediating osmotic and respiratory exchanges and provides a site for support / attachment of the body musculature and internal organs as reported by Antonelli, (2012). Other minute tegumental structures such as spines, setules, denticles and teeth may provide the principal interface between the organism and its external environment. Setae occurring on dorsal body surface have been considered the most likely receptors involved with the sensing of hydrodynamic disturbance (Razouls, 1996). Previous studies on some parasite copepods species indicate that they are sensitive to hydromechanical signals (Poulin et al., 1990). Parasitic copepods are sensitive to low-frequency water acceleration such as those produced by a swimming fish (Heuch and Karlsen, 1997). Pores, corresponding to the opening of secretary glands, observed on the surface of the body of L. kroyeri could intervene in the capture of preys by secreting a kind of mucus (Razouls, 1996). In copepods searching for food, chemoreception and mechanoreception work in conjunction.

In conclusion, the current study appeared that the tegument layers of Lernanthropus kroyeri is very similar to that described by Antonelli,(2012). Cuticular differentiations play a secondary role in the fixation and they have mainly a sensory function.

\section{References}

Abu Samak OA (2004) Redescription of Lernanthropus kroyeri (Copepoda: Lernenthropidae) infesting gills of sea bass fish (Dicentrarchus labrax) from Egyptian Mediterranean waters. J. Egypt. Ger. Soc. Zool., 43: 87-103.

Abu Samak OA (2005) Mode of attachment and histopathological impacts associated with the parasitic copepod Lernanthropus kroyeri infesting gills of the sea bass fish, Dicentrarchus labrax in Egypt. J. Egypt. Ger. Soc. Zool., 48: 1-21.

Antonelli L (2010) Impact du parasitisme sur la pisciculture en Corse. Suivi des parasitoses et étude des transferts de parasites depuis la faune sauvage vers les poissons élevés en mer ouverte. Thèse, Université de Corse, Pasquale Paoli.

Antonelli L (2012) Lernanthropus kroyeri (Van Beneden and Hesse 1851) parasitic Copepoda (Siphonostomatoidae, Lernanthropidae) of European cultured sea bass Dicentrarchus labrax (Linnaeus 1758) from Corsica: ecological and morphological study, Parasitol Res 110:1959-1968.

Boxshall GA, Yen J, Rudi Strickler J (1997) Functional significance of the sexual dimorphism in cephalic appendages of Euchaeta rimana Bradford. Bull Mar Sci 61:387-398.

Daszak P, Cunningham AA, Hyatt, AD (2000) Emerging infectious diseases of wildlife -Threats to biodiversity and human health. Science 287:443449. 
Dobson A, Foufopoulos J (2001) Emerging infectious pathogens of wildlife. Philosophical Transactions of the Royal Society of London Series B-Biological Sciences 356:1001-1012.

Ernst I, Whittington ID, Corneillie S, Talbot C (2002) Monogenean parasites in sea-cage aquaculture. Austasia Aquacult 16: 46-48.

FAO (2010) Food and Agriculture Organization of the United Nations: state of world aquaculture.

Fahmy, Sh A (2014) Studies on parasitic copepods of economically important fishes using modern techniques. Ph.D thesis, Damietta Univ. Egypt.

Ghittino C, Latini M, Agnetti F, Panzieri F, Lauro L, Ciapelloni R, Petracca A (2003) Emerging pathologies in aquaculture: effects on production and food safety. Vet Res Commun 27: 471-479.

Gresty KA, Boxshall GA, Nagasawa K (1993) Antennulary sensors of the infective copepod larva of the salmon louse Lepeophtheirus salmonis (Copepoda: Caligidae). In: Boxshall GA, Defaye D (eds) Pathogens of wild and farmed fish: sea lice. Ellis and Horwood, Chichester, pp 83-98.

Guo FC, Woo PTK (2009) Selected parasitosis in cultured and wild fish. Vet Parasitol 163: 207-216.

Heuch PA, Doall MH, Yen J (2007) Water flow around a fish mimic attracts a parasitic and deters a planktonic copepod. J Plank Res 29:i3-i6.

Heuch PA, Karlsen HE (1997) Detection of infrasonic water oscillations by copepodids, Lepeophtheirus salmonis, in step salinity gradients. J Mar Biol Ass 75:927-939.

Johnson SC, Treasurer JW, Bravo S, Nagasawa K, Kabata Z (2004) A review of the impact of parasitic copepods on marine aquaculture. Zool Stud 43:229-243.

Jones KE, Patel NG, Levy MA, Storeygard A, Balk D, Gittleman JL, Daszak P (2008) Global trends in emerging infectious diseases. Nature 451:990-994.

Khidr AA, Abu Samak OA, Said AE, Ghoneim AM, FahmyShA (2014) Structural and Functional Observations on the appendages of gill parasite, Lernanthropuskroyeri Lernanthropidae) infestinf the sea bass Dicentrarchuslabrax. Natue and Science 12: (2) 101-107.

Kuris AM, Hechinger RF, Shaw JC, Whitney KL, Aguirre-Macedo L, Boch CA, Dobson AP, Dunham EJ, Fredensborg BL, Huspeni TC, Lorda J, Mababa L, Mancini FT, Mora AB, Pickering M, Talhouk NL, Torchin ME, Lafferty KD (2008) Ecosystem energetic implications of parasite and free-living biomass in three estuaries. Nature 454: 515-518.

Lafferty KD, Allesina S, Arim M, Briggs CJ, De Leo G, Dobson AP, Dunne JA, Johnson PTJ, Kuris AM,
Marcogliese DJ, Martinez ND, Memmott J, Marquet PA, McLaughlin JP, Mordecai EA, Pascual E, Poulin R, and Thieltges DW(2008) Parasites in food webs: the ultimate missing links. Ecology Letters 11: 533-546.

Lee CS, O’Bryen PJ, Marcus NH (2005) Copepods in aquaculture. Blackwell Publishing, Oxford, UK.

Manera M, Dezfuli BS (2003) Lernanthropus kroyeri infections in farmed sea bass Dicentrarchus labrax: pathological features. Dis Aquat Organ 57:177-180

McKenzie VJ (2007) Human land use and patterns of parasitism in tropical amphibian hosts. Biological Conservation 137:102-116.

Mladineo I, Marsic-Lucic J (2007) Host switch of Lamellodiscus elegans (Monogenea: Monopisthocotylea) and Sparicotyle chrysophrii (Monogenea: Polyopisthocotylea) between cagereared sparids. Vet Res Commun 31:153-160.

Morand S, Krasnov BR (2010) The Biogeography of Host-Parasite Interactions. Oxford University Press, Oxford.

Noga EJ (2000) Fish disease. Diagnosis and treatment. Wiley- Blackwell, Ames, IA.

Ohtsuka S, Huys R (2001) Sexual dimorphism in calanoid copepods: morphology and function. Hydrobiologia 453:441-466.

Ozel I, Oktener A, Aker V (2004) A morphological study (SEM) on a parasitic copepod: Lernenthropus kroyeri (Van Beneden, 1851). J Fish Aquat Sci 21:335-337.

Poulin R, Curtis MA, Rau ME (1990) Responses of the fish ectoparasite Salmincola edwardsii (Copepoda) to stimulation, and their implication on the host finding. Parasitology 100:17-421.

Ragias V, Tontis D, Athanassopoulou F (2004) Incidence of an intense Caligus minimus Otto 1821 , C. pageti Russel, 1925, C. mugilis Brian, 1935 and C. apodus Brian, 1924 infection in lagoon cultured sea-bass (Dicentrarhus labrax L.) in Greece. Aquaculture 242:727-733.

Raibaut A, Combes C, Benoit F (1998) Analysis of the parasitic copepod species richness among Mediterranean fish. J Mar Syst 15:185-206.

Razouls C (1996) Diversité et repartition géographique chez les copepods pélagiques. 2- Platycopoida, Misophrioida, Cyclopoida, Poecilostomatoida, Siphonostomatoida, Harpaticoida, Monstrilloida. Ann Inst Océano, Paris, nouvelle série 72:1-149.

Toksen E, Cagirgan H, Tanrikul TT, Saygi H (2006) The effect of Emamectin Benzoate in the control of Lernanthropus kroyeri (Van Beneden, 1851) (Lernanthropidae) infestations in culturedsea-bass, Dicentrarchus labrax (Linné, 1758). Turk J Vet Anim Sci 30:405-409. 


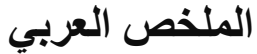

عنوان البحث: الأشكال الاقيقة لبعض التركيبات الجليدية للطفيلي مجدافي الأرجل ليرنانثروبس كرويري

$$
\text { قرين علم الحيوان - كلية العلوم - جامعة دمياط ـ دمياط ـ مصر }
$$

استهلتث الداسة الحالية القيام بعمل دراسات على الطفيليات مجدافية الأرجل التي تصيب أحد الأسماك

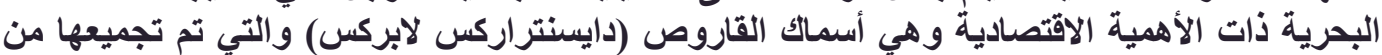

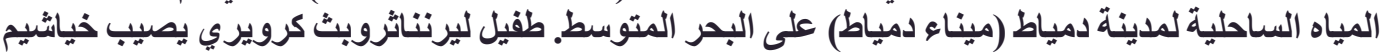

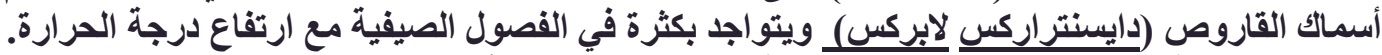

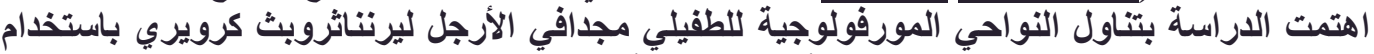

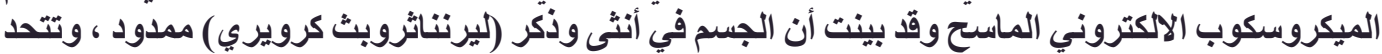

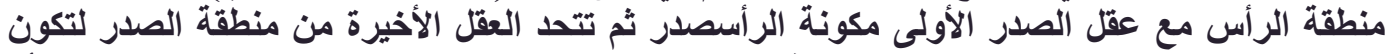

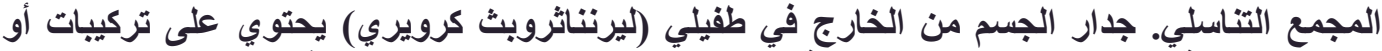

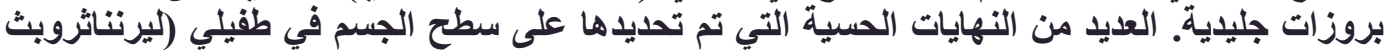

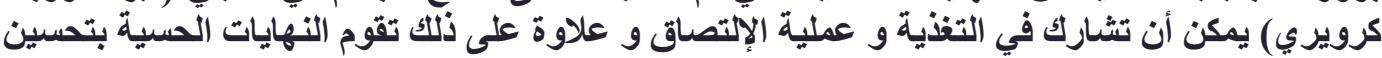

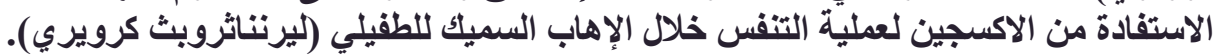

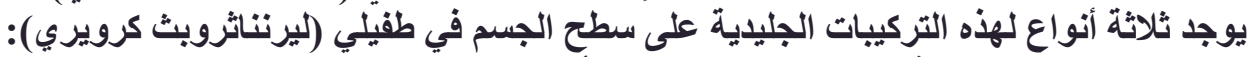

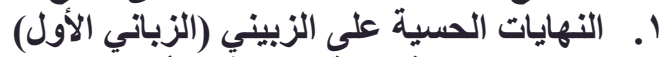

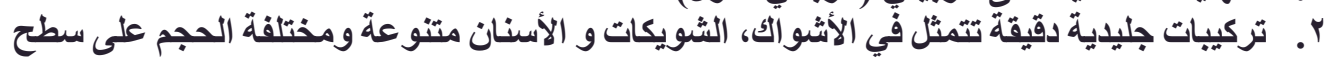

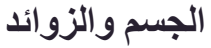

r. ت تراكيب حسية غير مهدبة مثل الحلمات الحسية و النتوعات الحسية على كل سطح الجسم ماعدا الزبينيان والأرجل الفكية للطفيلي تئل

Ultrastructural features of some integumental structural of Lernanthropus kroyeri Van . . Beneden parasitic copepoda (Siphonostomatoidae, Lernanthropidae) 